
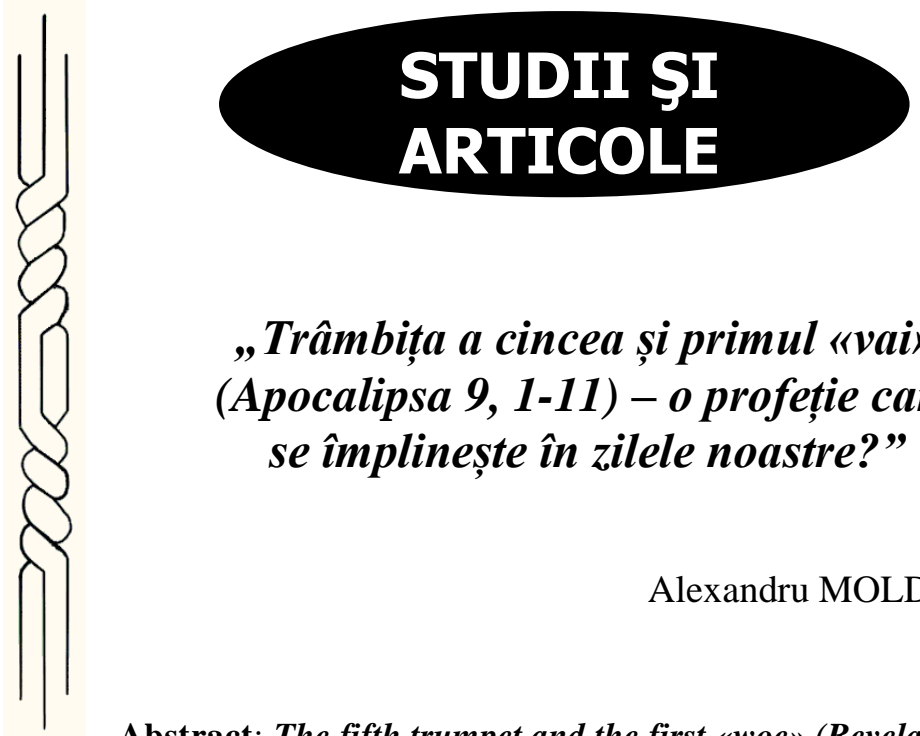

\title{
„Trâmbița a cincea și primul «vai»» (Apocalipsa 9, 1-11) - o profeție care se împlinește în zilele noastre?"
}

\section{Alexandru MOLDOVAN*}

Abstract: The fifth trumpet and the first «woe» (Revelation 9, 111) - a prophecy which fulfills nowadays? The book of the Revelation has always caused its readers to have comprehension difficulties and especially to feel a certain fear because of the repeated allusions the author makes "to the end times", but also because of its affecting and impressive scenes, with a catastrophic tendency. This is the source of the negative meanings acquired by the word "apocalypse" in almost all modern languages and in the common thinking of people. At the same time, nevertheless, the text of this book continues to fascinate and attract the exegetes and the readers through its mysterious language, imbued with symbols, as well as through its numerous visions with a prophetic character. A testimony of this is that this book had a decisive influence on art, culture, universal literature and cinematography.We aim in this study at reading, but especially at analysing in depth one of the pericopes of this book - Revelation 9, 1-11 - and its theological message and we attempt to relate it to the times we are living, to our concrete life: ecclesial and social.The religious message of the Revelation addresses primarily the faithful, as the one who approaches God must first believe that God exists,

* Preot, Conferențiar Universitar Doctor, Facultatea de Teologie Ortodoxă, Universitatea „1 Decembrie 1918” din Alba Iulia, România. 
because one cannot approach something which does not exist (Hebrews $11,6)$, but under no circumstance does this mean that the people who believe in God have "exclusivity" in understanding this book. Nonbelievers, free-thinkers and agnostics are also "welcome", however, the questions they will ask the book will receive various answers, depending on each one's perspective.

Keywords: Revelation, testimony, witness, theological message, sacrifice, symbol, ,the faithful Witness", the bottom less pit, abyss, cloud of locusts, the Kingdom of Christ.

\section{Preliminarii}

Cartea Apocalipsei a provocat întotdeauna în cititorii ei dificultăți de înțelegere și, mai ales, o anumită teamă, datorită repetatelor aluzii pe care autorul ei le face la ,timpurile din urmă”, dar și din cauza scenelor ei tulburătoare, impresionante, cu tentă catastrofală. De aici provin accepțiile hotărât negative ale cuvântului ,apocalipsă" în mai toate limbile moderne și în concepția comună aoamenilor. În același timp, însă, textul acestei cărți continuă să-i fascineze și să-i atragă pe exegeți și pe comentatori, dar și pe cititori, atât prin limbajul său misterios, îmbibat cu simboluri, cât și prin numeroasele viziuni cu un evident caracter profetic. Că este aşa stă mărturie faptul că această carte biblică a influențat în mod decisiv arta, literatura universală și cinematografia ${ }^{1}$. Incepând din Antichitate, și până în timpurile moderne, textele sau pericopele ei arcane și enigmatice au fost exploatate de interpreți fanatici și de eretici, dar și de sectele și de mișcările reformatoare moderne. Acesta a fost unul dintre numeroasele motive care au făcut dificilă acceptarea acestei cărți în canonul Sfintei Scripturi ${ }^{2}$.

Ultima carte a Sfintei Scripturi aparține genului numit ,apocaliptic”, ilustrat deja în paginile Vechiului Testament de

${ }^{1}$ Giancarlo BiguzzI, L 'Apocalisse e $i$ suoi enigmi (Studi ed Esegesi Biblica 143), Brescia, Paideia Editrice, 2004, p. 33.

2 Luca Pedroli, Presentazione del libro di Ugo VANNI, Apocalisse di Giovanni, Primo volume, Assisi, Cittadella Editrice, 2018, p. 5. 
„Trâmbița a cincea și primul «vai» (Apocalipsa 9, 1-11) o profeție care se implinește în zilele noastre?"

profetul Daniel, dar și de profetul Iezechiel și de ceilalți profeți, dar destul de cultivat în perioada intertestamentară și în primul secol al erei creștine. În timpul în care a fost scrisă această carte, înțelesul mai exact al cuvântului grecesc „'А de ,a dezvălui”, „a descoperi ceva ascuns”,,a da la o parte vălul” care acoperă tainele lui Dumnezeu. Prin urmare, și Apocalipsa Sfântului Ioan, deși inspirată și canonică, folosește din plin toate mijloacele şi procedeele literare ale genului, precum aproximația (ambiguitatea artistică), hiperbola (exagerarea și supradimensionarea), fantasticul, pseudonimia, dar mai ales simbolismul (al culorilor, al pietrelor și, în primul rând, al numerelor). Toate acestea, menite în alte circumstanțe să deconcentreze, sub pana Sfântului Ioan capătă transparență, unitate și sens, în scene tulburătoare de o mare densitate simbolică, în care prevalează gustul autorului pentru ordine, simetrie și mișcare dramatică, un gust care reușește să învingă precaritatea limbii grecești în care e scrisă opera ${ }^{3}$.

Începând cu secolul al II-lea, Apocalipsa Sfântului Ioan a fost acceptată în comunitățile creștine, iar în epoca patristică a fost interpretată alegoric și într-o perspectivă pascală, ca o prezentare elegantă și rafinată a modului în care planul de mântuire al lui Dumnezeu s-a împlinit în istorie, plan prefigurat deja în paginile Vechiului Testament în istoria zbuciumată a poporului ales ${ }^{4}$. De aici, trimiterile repetate la cărțile Vechiul Testament în orizontul unei împliniri eshatologice percepută deja ca fiind în devenire sau în curs de realizare.

Această interpretare alegorică a Apocalipsei s-a impus și a predominat mai mult de un mileniu în Biserică, traversând mai întâi epoca patristică, apoi a continuat cu o interpretare spirituală, specifică comentatorilor medievali.

O schimbare radicală s-a petrecut la sfârșitul secolului al XIIlea, când filozoful și teologul calabrez Ioachim din Fiore, considerat

${ }^{3}$ Biblia sau Sfânta Scriptură. Introducere la Apocalipsa Sfântului Ioan Teologul, București, Edit. Institutului Biblic și de Misiune Ortodoxă, 2018, p. 1535.

${ }^{4}$ Anna Barzaghi, Apocalisse di Giovanni. Con commenti tratti dai Padri, Santi e Mistici della Chiesa, Bari, Edizioni Pugliesi, 2003, p. 18. 
iniţial profet, iar apoi eretic, în opera sa intitulată: „Enchiridion super Apocalypsim" a propus înțelegerea acestei cărți ca o profeție în adevăratul sens al cuvântului, care descrie și subliniază fazele istoriei mântuirii ${ }^{5}$. Începând cu acel moment, s-a mers în derivă în ceea ce privește citirea și interpretarea Apocalipsei, fapt care a relansat interesul comentatorilor pentru această carte, înțeleasă ca o minunată prevestire a faptelor istorice care trebuie să se petreacă în prezent sau în viitor. De aici, abordarea sau interpretarea literală a cărții, plină de fantezie, extravagantă, exploatată și în zilele noastre, interpretare care a condus la rezultate exagerate și complet nefondate.

Autorii moderni au încercat să remedieze această tendință de interpretare preponderent literală, care s-a impus în ultimele secole în cercetarea biblică, cu interpretări improvizate și cu încercarea de a înțelege cartea Apocalipsei ca o prevestire a unor catastrofe iminente și a sfârșitului lumii.

Începând cu secolul al XIX-lea, asistăm la o reașezare a textului Apocalipsei pe făgașul ei teologic și eclezial de la începuturi. În acest sens, există studii care plasează cartea Apocalipsei în cadrul experienţei primelor comunităţi creştine, în contextul istoric de la sfârşitul primului secol şi de la începutul celui de-al doilea secol creștin, cu o puternică legătură, atât cu tradiția iudaică, cât și cu cultura greco-romană ${ }^{6}$.

Alți autori, în schimb, luând în considerare trimiterile la fondul iudaic al cărții și, împreună cu acestea, la imaginarul cosmic și mitologic, au interpretat această carte exclusiv în sens eshatologic, cu referire la Parusie și la sfârșitul timpurilor ${ }^{7}$. Alții au supus-o unei analize strict literale și într-o perspectivă exclusiv

5 Andrea Tagliapetra, Gioacchino da Fiore. Sull'Apocalisse, Milano, Editrice Feltrinelli, 1994, p. 33.

${ }^{6}$ Gregory K. BeAle, The Book of Revelation. A Commentary on the Greek Text, New International Greek Testament. Commentary. Michigan - United Kingdom, Grand Rapis - Cambridge, 1999, p. 67.

7 Angelo Lancellotti, Apocalisse. Nuovissima Versione della Bibbia 46, Roma, Edizioni Paoline, 1981. A se vedea și Silverio ZEDDA, „L'Escatologia dell'Apocalisse", în L'escatologia biblica, Vol. 2, Brescia, 1974, p. 427-515. 
„Trâmbița a cincea și primul «vai» (Apocalipsa 9, 1-11) o profeție care se implinește in zilele noastre?"

istorică, așezând-o în continuarea literaturii apocaliptice iudaice, sau înțelegând-o ca pe o împlinire a istoriei și a experienței poporului biblic, așa cum este descrisăaceasta în paginile Vechiului Testament $^{8}$.

În sfârșit, în timpurile mai recente, comentatorii și exegeții Apocalipsei și-au dat seama că această carte nu poate fi studiată și interpretată numai din punct de vedere istoric și literar, dar nici numai dintr-o perspectivă eshatologică. Din această conștientizare s-a născut imboldul de a aprofunda simbolismul cărții, pentru a-i descoperi bogăția teologică. Astfel, a revenit în prim-plan lectura pascală a credinței creștine și a vieții Bisericii ${ }^{9}$, lectură ilustrată admirabil în această carte biblică.

Referindu-se la textul Apocalipsei - în special, la cuvintele ei pline de fascinație și de mister - Fericitul Ieronim își exprima astfel aprecierea plină de entuziasm față de această carte: „Apocalipsa lui Ioan are multe taine ascunse în cuvintele ei, iar cu astaam spus destul de puțin față de valoarea ei inestimabilă. Orice laudă i-aș aduce, niciuna nu ar fi la înălțimea ei: în cuvintele ei se ascund multe sensuri și semnificații adânci"10.

Trecând $\mathrm{cu}$ vederea alte considerații posibile pe marginea acestei cărţi, Fericitul Ieronim s-a oprit asupra cuvintelor ${ }^{11}$ ei, afirmând un paralelism interesant între cuvintele Scripturii și

8 Bruno Corsani, L'Apocalisse e l'apocalittica del Nuovo Testamento, Bologna, 1997; Edmondo LuPIERI, L'Apocalisse di Giovanni (Scrittori greci e latini), Milano, 1999. Severino Dianich, Sempre Apocalisse. Un testo biblico e le sue risonanze storiche, Casale Monferrato, Editrice Piemme, 1998; Eugenio Corsini, Apocalisse di Gesù Cristo secondo Giovanni, Torino, SEI, 2002.

${ }^{9}$ Pierre Prigent, L'Apocalisse di San Giovanni (Collana Commenti Biblici), Città di Castello, Edizioni Borla, 1985. Titlul original al operei: L'Apocalypse de Saint Jean (Commentaire du Nouveau Testament 14), Lausanne-Paris, Delachauxet Niestlé, 1981, p. 46.

10 ,Apocalypsis Joannis tot habet sacramenta, quot verba. Parum dixi pro merito voluminis. Laus omnis inferior est: in verbis singulis multiplices latent intelligentiae". Fericitul Ieronim, Ad Paulinum 53, 8, anul 394.

11 Substantivul „cuvânt” poate fi înțeles, în sens general, ca un simplu termen, sau poate dobândi, determinat de contextul în care apare, un sens special, un sens deosebit, în cazul precis al Apocalipsei, acela de „cuvânt inspirat”. 
Sfintele Taine, înțelese în sensul unei implicări active (dinamice) în dezvoltarea tainei mântuirii, care atinge transcendența.

Importanța extraordinară pe care o dobândesc cuvintele este accentuată de Fericitul Ieronim care afirmă că acestea conțin sau cuprind în ele o posibilitate, de conținut și de acțiune, ascunsă și multiplă. Cuvântul inspirat este cel care menține amprenta sau pecetea permanentă și activă a Duhului lui Dumnezeu. Se înțelege astfel cum cuvântul, rămânând sau păstrând formularea sa proprie, la singular sau la plural, poate să cuprindă în el sensuri şi semnificații teologice multiple ${ }^{12}$.

Cuvintele la care face referire Fericitul Ieronim coincid cu expresia literară a textului, concretizată în elementele sale gramaticale semnificative - verbul, substantivul, adjectivul și adverbul etc. - folosite în comunicarea conținutului, care este perceput și elaborat de cititorul sau de ascultătorul textului ${ }^{13}$.

Însă, alături de morfologia și sintaxa frazei, își dau concursul și alte elemente care intervin pentru a califica în moduri deferite cuvântul autorului sfânt, cum ar fi alăturările de cuvinte, paralelismele, sublinierile emfatice și parantezele. Fiecare dintre aceste elemente influențează conținutul textului și este nevoie, atunci când purcedem la analiza unei pericope biblice din cuprinsul Apocalipsei, să ținem cont de acest lucru și să analizăm cu atenție fiecare cuvânt și să-1 determinăm să ne descopere sensul și taina pe care le conține.

Dacă vom parcurge foarte atent aceste etape, la sfârşitul acestui demers exegetic cuvântul lui Dumnezeu va ,palpita”, se va manifesta cu putere și va vibra în sufletele noastre! Prezentat și primit

12 Este propriu cuvântului lui Dumnezeu un efect special care poate depăşi în mod clar și evident orice cuvânt omenesc. Acest lucru este exprimat și în exegeza rabinică: hermeneutica rabinică pleacă de la presupunerea că fiecare cuvânt al Torei are şaptezeci de sensuri. Cf. Ugo VANNI, Apocalisse di Giovanni, Primo volume, Assisi, Cittadella Editrice, 2018, p. 25-26.

13 Textul Apocalipsei, fiind destinat citirii în adunarea liturgică, presupune un cititor și un auditor, așa cum ne indică versetul 3 al primului capitol: „Fericit este cel ce citește și cei ce ascultă cuvintele proorociei şi păstrează cele scrise în aceasta!'. Acest fapt condiționează stilul folosit de autorul cărții, limitând la maximum subordonările sintactice grecești, mai puțin adaptate unei lecturi ascultate, care preferă parataxa sau juxtapunerea. 
„Trâmbița a cincea și primul «vai» (Apocalipsa 9, 1-11) o profeție care se implinește în zilele noastre?'

cu sensul său adânc și cu toate nuanțele pe care le conține, cuvântul lui Dumnezeu va fi în măsură să-și atingă, în sfârșit, scopul și menirea, instaurând în toți și în toate noutatea lui Hristos Cel Înviat de care cuvântul inspirat este purtătoare. Se întâmplă atunci tocmai ceea ce afirmă Apocalipsa într-o pericopă memorabilă scrisă spre finalul ei: „Și Cel ce ședea pe tron a grăit: Iată, noi le facem pe toate. Și a zis [aici vorbește îngerul care-i interpretează lui Ioan mesajul]: Scrie, fiindcă aceste cuvinte sunt vrednice de crezare și adevărate. Și iar mi-a zis: [aici e din nou Dumnezeu care vorbește]: Făcutu-s-a! Eu sunt Alfa și Omega, Începutul și Sfârșitul” (Apocalipsa 21, 5-6a). Fericitul Ieronim a văzut și a înțeles bine: în cuvintele Apocalipsei există o dimensiune care ne atinge și, în același timp, ne depășește. Cuvintele - așa cum vom vedea - tind să sădească în om și în lume infinitul noutății Celui Înviat.

Cartea Apocalipsei este unică, în felul ei, în canonul Noului Testament, dar, așa cum am spus, nu e singura care aparține „genului apocaliptic” în cuprinsul Bibliei în ansamblu, deoarece acest gen literar apare şi în paginile Vechiului Testament (cu precădere la Profeții biblici, în special la profetul Daniel și la profetul Iezechiel), dar și în perioada dintre cele două Testamente, genul apocaliptic fiind un descendent al genului profetic.

Apocalipsa a stârnit mereu interesul, dar, mai ales, curiozitatea omului. Dar asta nu-i suficient! Apocalispa e o carte dificilă, greu de interpretat sau de tâlcuit și greu de înțeles. Ea a cunoscut multe traduceri și multe interpretări, cele mai multe dintre acestea nefiind altceva decât răstălmăciri neinspirate ${ }^{14}$.

Ceea ce ne propunem prin acest studiu este să citim, dar mai ales, să privim mai în profunzime conținutul și mesajul teologic al acestei cărți, pe cât de criticată, pe atât de apreciată, și să încercăm să raportăm mesajul ei teologic timpului pe care-1 trăim, vieții noastre concrete (eclezială și socială).

Cred că prima întrebare - poate și cea mai grea - pe care ne-o punem, atunci când vorbim despre cartea Apocalipsei, este legată

${ }^{14}$ Ugo Vanni, Apocalisse, libro della Rivelazione. Esegesi biblico-teologica e implicazioni pastorali, Bologna, Edizioni Dehoniane, 2009, p. 7. 
de timpul istoric pe care-1 trăim și de starea de îngrijorare pe care a produs-o oamenilor din întreaga lume noua pandemie SARS-CoV-2. Să fie, oare, mai „dramatic” timpul prezent decât au fost timpurile trecute? Omenirea are o istorie complexă și complicată, de foarte multe ori dramatică, care, uneori, entuziasmează, însă de cele mai multe ori înfricoșează!

Față de istoria pe care o trăim, și în care suntem înglodați până-n gât, Apocalipsa are un mesaj pentru noi și ne determină să ne punem unele întrebări dificile: „Care este sensul evenimentelor care marchează astăzi istoria noastră?”; „Care este responsabilitatea (sau partea) noastră față de aceste evenimente?”; „Cum ar trebui să ne raportăm la ele?".

Pentru aceste interogativeApocalipsa are un răspuns, are un „mesaj religios”, care este într-o legătură directă cu evenimentele istoriei. După exemplul lui Hristos, Care S-a întrupat în istorie, S-a făcut Om adevărat, Apocalipsa ne învaţă să trăim implicați, spiritual și responsabil, în ,venele timpului”.

O precizare importantă: mesajul religios sau teologic al Apocalipsei se adresează, în primul rând, oamenilor credincioși, pentru că cel ce se apropie de Dumnezeu trebuie să creadă, mai întâi, că Dumnezeu există, deoarece nu te poți apropia de ceea ce nu există: „Fără credință, dar, nu este cu putință să fim plăcuți lui Dumnezeu, căci cine se apropie de Dumnezeu trebuie să creadă că El există (este) și că El Se face răsplătitor celor care-L caută" (Evrei $11,6)$. Dar asta nu înseamnă în niciun caz că oamenii care cred în Dumnezeu au „exclusivitate” în ceea ce privește citirea şi înțelegerea acestei cărți. Sunt ,admiși” și necredincioșii, libercugetătorii și agnosticii, însă întrebările pe care aceștialevor pune cărții vor primi răspunsuri diferite, în funcție de perspectiva din care privește fiecare.

\section{Perspectivă generală asupra seriei trâmbițelor}

Ultima carte a Bibliei este numită, în limba greacă,

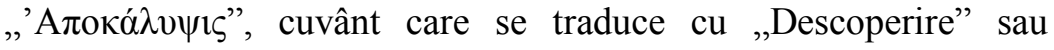


„Trâmbița a cincea și primul «vai» (Apocalipsa 9, 1-11) o profeție care se implinește in zilele noastre?"

„Revelație”, cu ,a da un văl la o parte” sau ,a descoperi ceva ascuns". Dar ce anume e acest ,văl”? Potrivit dicționarului, expresia ,a i se pune (sau a i se lua cuiva) un văl (de) pe ochi”, se traduce cu: ,a înceta (sau a începe) să vadă, să judece limpede sau să înțeleagă ceva”. În cazul Apocalipsei, acest „văl” acoperă, ascunde sau împiedică înțelegerea sensurilor sau a semnificațiilor profunde ale evenimentelor istoriei ai cărei protagoniști suntem și noi. În sens religios, a înlătura vălul înseamnă a cunoaşte și a înțelege planul (sau proiectul) lui Dumnezeu asupra istoriei umane.

Textul propus spre reflecție în studiul de față - Apocalipsa 9, 1-11 - face parte dintr-o secțiune sau dintr-o serie mai extinsă, numită în comentariile biblice: „Seria trâmbițelor”, secțiune alcătuită din capitolele $8,9,10$ și 11 .

Din capul locului trebuie spus că intervențiile lui Dumnezeu în istoria noastră, chiar și cele care se exprimă într-o formă izbitoare și tulburătoare sau înfricoșătoare, nu reprezintă o „revanșă punitivă" a lui Dumnezeu în ceea ce ne privește! Dumnezeu nu e ca omul și nici nu spune: „Ai făcut ceva rău, iar acum te pedepsesc!”. Atunci când Dumnezeu îngăduie să se întâmple unele lucruri sau evenimente neplăcute și nedorite, El lansează un avertisment, sau face un apel, spunându-ne: ,Atenție! Sunteţi pe un drum greşit!’. El avertizează lumea că, dacă încearcă să construiască o cetate ${ }^{15}$, ignorând legătura cu Creatorul său, ori tăind legătura cu Cerul, neglijând în mod constant latura noastră spirituală, această cetate va cădea sub influența celui Rău, iar demersul oamenilor va devia întro ,anticreaţie”.

Diavolul a încercat mereu să construiască o lume fără Dumnezeu, o umanitate lipsită de orizontul transcendenței, o lume contrară sau potrivnică lui Dumnezeu, și nu doar indiferentă față de existența Lui. O umanitate care - așa cum se vede în „Seria trâmbițelor" - se orientează și capătă o traiectorie sau o tendință de secularizare, de laicizare, de separare față de Dumnezeu, demers care riscă să „,contamineze” în mod inexorabil lumea noastră fizică, biologică și naturală.

${ }^{15}$ A se vedea episodul „Turnului Babel” din Cartea Facerea, capitolul 11. 
Dumnezeu este prietenul omului - Dumnezeu Însuși S-a făcut Om adevărat -, iar omul are nevoie de Dumnezeu. Dumnezeu Însuși, într-un anume fel, are nevoie de om, are nevoie de un prieten. Acest lucru presupune neapărat o „reciprocitate în iubire”"16.

Dacă privim din acest unghi sau din această perspectivă, intervențiile Celui Atotputernic în istoria umană reprezintă „un avertisment simbolic", adresat oamenilor. Care este conținutul acestui avertisment? Dacă vreți să construiți o lume sau o societate fără Dumnezeu, această lume se va prăbuși! Acest lucrunu se va întâmpla printr-o intervenție „din afară” sau „din exterior”, ci datorită slăbiciunii intrinseci a unei lumi gândite și construite împotriva voii lui Dumnezeu. O lume sau o societate edificată sau construită fără Dumnezeu va crăpa „din interior”, deoarece are o temelie șubredă și „,un defect major din fabrică” sau „o eroare în proiectul de constructie", un defect de fond, elementar: indiferența, refuzul și opoziția față de planul lui Dumnezeu, adevăratul autor sau adevăratul „Arhitect” al lumii ${ }^{17}$.

Prin urmare, cutremure, tsunami, erupții vulcanice, distrugeri, războaie, epidemii, boală și moarte sunt, în paginile Sfintei Scripturi, paradigme sau categorii simbolice care urmăresc să scoată în evidență gravitatea erorilor pe care le fac oamenii, făpturi raționale, înzestrate cu voie liberă, spre propria lor pagubă. Dacă Dumnezeu insistă să vestească, dar mai ales să pună în aplicare, „mânia” Lui, El o face cu „pasiunea îndrăgostitului” care nu suportă să-și vadă ,iubita” (adică lumea sau sufletul omului) aruncându-se în brațele idolilor de nimic. Dumnezeu Se mânie și Se întristează atunci când făptura Sa cea mai dragă face greșeli sau erori fatale ${ }^{18}$.

Septenarul sau seria trâmbițelor se desfășoară începând cu versetul 6 al capitolului 8 până la capitolul 11 în întregime. Dacă privim în ansamblu această secțiune, vom observa un detaliu literar interesant: îngerii lui Dumnezeu sună din trâmbițe, iar la

${ }^{16}$ Ugo VAnNi, Apocalisse, libro della Rivelazione, p. 93.

17 Giancarlo BIGUZZI, Apocalisse. Nuova versione, introduzione e commento (I Libri Biblici. Nuovo Testamento 20), Milano, Edizioni Paoline, 2011, p. 74.

${ }^{18}$ Ugo VanNi, Apocalisse, libro della Rivelazione, p. 94. 
„Trâmbița a cincea și primul «vai» (Apocalipsa 9, 1-11) o profeție care se implinește in zilele noastre?"

fiecare sunet de trâmbiță avem o vizualizare concretă a unei pagini din sulul de carte, sul care conține planul sau proiectul lui Dumnezeu asupra lumii. Planul lui Dumnezeu se descoperă treptat omului, iar acesta din urmă îl poate citi și interpreta. Acelaşi lucru s-a întâmplat mai devreme în cazul septenarului peceților la deschiderea fiecăreia dintre ele. Prin urmare, și de data aceasta, fiecărui sunet de trâmbiță îi urmează un eveniment impresionant, de mari proporții, iar vizionarul și cititorul cărții pot citi o pagină a sulului de carte ${ }^{19}$.

\section{Apocalipsa 9, 1-11 - Trâmbița a cincea și primul ,vai”}

Sunetul celei de-a cincea trâmbițe este prefațat de glasul unui vultur care striga cu glas mare din înaltul cerului: „Vai, vai, vai celor ce locuiesc pe pământ" (Apocalipsa 8, 13). Dacă traducem adlitteram textul original grecesc, atunci vom avea o variantă ușor diferită: „Vai, vai, vai, celor ce-și construiesc casa pe pământ” (și nu pe piatră $)^{20}$. Textul acesta nu vorbește despre oamenii care locuiesc pe pământ într-o locuință provizorie (într-un cort ${ }^{21}$ ), ca străini și călători ${ }^{22}$, ci despre cei care se raportează numai și în mod exclusiv la pământ în viața aceasta, rupând orice legătură cu transcendența. Prin gestul lor, aceștia intră sub stăpânirea sistemului demoniac-terestru care are drept caracteristică fundamentală o pretenție de autosuficiență absolută ${ }^{23}$. Avertismentul Domnului este cât se poate de clar: această autosuficiență și acele case zidite sau construite pe pământ se vor prăbuşi.

Întreita repetare a interjecției ,vai” are, fără îndoială, un caracter peremptoriu, dar nu e o amenințare punitivă. Este, mai

19 Pierre Prigent, L 'Apocalisse di S. Giovanni (Commenti biblici), Roma, Edizioni Borla, 1985, p. 513.

20 A se vedea metafora celor două case evocată de Mântuitorul Hristos Însuși în finalul Predicii de pe Munte (Matei 7, 24-27).

${ }^{21}$ Imagine care evocă trupul nostru biologic (2 Corinteni 5, 1. 4).

221 Petru 2, 11.

${ }^{23}$ Ugo VAnNi, Apocalisse, libro della Rivelazione, p. 95. 
degrabă, un emoționant apel la pocăință adresat pământenilor, celor care se raportează numai la pământ, celor care cred că sunt numai pământ și care, prin alegerea lor, aparțin sistemului de organizare și de conducere pământesc ${ }^{24}$. Dacă apelul la pocăință va fi auzit și ascultat, cei care aparțin pământului vor trece de sub stăpânirea sistemului antihristic în Împărăția lui Hristos. În caz contrar, situaţia lor devine iremediabilă; în cazul lor vorbim despre un faliment iremediabil, căci soarta lor va fi pecetluită. Prin urmare, miza propusă în acest text este foarte mare. Numai așa se poate explica ,pathosul” cu care vulturul dă glas unui ,,vai” întreit, unui ,vai” la puterea a treia. E ca și cum ar fi strigat: „Greșiți, greșiți, greșiți!”.

Vom vedea că a cincea, a șasea și a șaptea trâmbiță coincid cu cele trei ,vai"'-uri sau cu cele trei plângeri. Cele trei „,vai”-uri sunt personalizate, iar noi putem spune despre ele că sunt aspecte înlănțuite ale vieții care se desfăşoară astăzi pe pământ.

Dumnezeu a încredințat oamenilor creația, lucrurile pe care le-a adus la ființă sau la existență. El vrea ca omul să-și aducă propria contribuție la cunoașterea $l^{25}{ }^{25}$, însă omul nu se poate juca cu acest dar. Creația lui Dumnezeu n-ar fi completă fără participarea activă a omului. Din acest motiv, Dumnezeu solicită implicarea responsabilă a omului în creație, dar în direcția dorită sau voită de Dumnezeu Însuşi, adică în avantajul tuturor oamenilor. Tendințele unora de a se izola în autosuficiență şi de a căuta numai și în mod exclusiv propriul lor profit, fără a se gândi la ceilalți, reprezintă o atitudine distructivă, tipică sistemului de organizare pământesc.

Dar până unde se va putea întinde această tendință negativă? Tentativa aceasta s-ar putea extinde asupra cosmosului şi ar putea avea efecte negative asupra luminătorilor pe care Domnul Dumnezeu i-a pus pe firmament. Cum se va întâmpla acest lucru este greu să ne imaginăm. Știința însăși nu e încă în măsură să ne

${ }^{24}$ Giancarlo BiguZZI, Apocalisse. Nuova versione, introduzione e commento, p. 76.

${ }^{25}$ Fapt ilustrat simbolic prin faptul că Adam (omul) a pus sau a dat un nume lucrurilor aduse la existență (Facerea 2, 19-20). 
„Trâmbița a cincea și primul «vai» (Apocalipsa 9, 1-11) o profeție care se implinește în zilele noastre?'

răspundă la această întrebare, dar nici nu poate exclude faptul că acest scenariu este posibil ${ }^{26}$.

Dacă omul va merge înainte pe acest drum - și va merge negreșit - pe drumul cunoașterii legilor încă necunoscute ale naturii, descoperirile lui vor schimba fața lumii în care trăim, dacă nu cumva au și început s-o facă... E suficient să ne gândim, de pildă, la descoperirea și la folosirea internetului: acest fapt a revoluționat, la propriu, viața și cultura popoarelor de pe mapamond ${ }^{27}$.

Speranța noastră este aceea că descoperirile moderne ale tehnicii vor fí folosite în funcție de binele comun al umanității, în funcție de binele ficărui om în parte și în funcție de binele comun și că nu se vor supune unor interese egoiste și meschine, oligarhice, și că ele nu vor sluji interesele unor grupuri de interese financiare, economice sau politice. Dacă se va întâmpla acest lucru, către ce țintă se va îndrepta omenirea? Intrebarea aceasta trebuie să ne-o punem. Oare am putea exclude, în mod aprioric, că soarele nostru se va stinge la un moment dat și că luna nu-și va mai da lumina ei? Că stele cerului vor cădea? Nu putem exclude acest lucru.

Din acest motiv, autorul Apocalipsei se adresează sistemului terestru care guvernează lumea şi popoarele: „Fiţi atenţi! Ați apucat-o pe un drum greşit! Ați apucat-o pe un drum care va duce la distrugerea umanităţii! El repetă cu insistență: „Reflectaţi! Fiţi responsabili față de sarcina pe care Creatorul v-a dat-o de a duce la plinire, împreună cu El, creația Sa”.

\section{Profilul literar și teologic al pericopei}

Așadar, trâmbița a cincea coincide cu primul dintre cele trei „vai”-uri. La sunetul ei, vizionarul a văzut o stea care a căzut din cer pe pământ.Suprapunându-se ultimelor trei trâmbițe, cele trei „vai”-uri creează efectul literar al unei accentuări dramatice și sugerează aspectul teologic al unui crescendo, al unei dezvoltări ulterioare ale mișcării apocaliptice. Construcția literară a pericopei

${ }^{26}$ Pierre Prigent, L 'Apocalisse di S. Giovanni, p. 533.

${ }^{27}$ Ugo VAnNi, Apocalisse, libro della Rivelazione, p. 96. 
este foarte rafinată, întrucât începe cu o referire la „fântâna adâncului" care se deschide (Apocalipsa 9,2) și se încheie cu aluzia la ,îngerul adâncului" (Apocalipsa 9, 11) care are puterea de a trage după el forțele ostile.

Între aceste două extreme avem o mișcare literară în două faze. Cea dintâi se desfășoară în crescendo: la deschiderea fântânii adâncului, s-a ridicat un fum gros „,ca fumul unui furnal” (Apocalipsa 9,2) care a întunecat fața pământului. Din acest fum gros ,au ieșit lăcuste pe pământ”, iar lăcustele îi tulbură și îi atacă pe oameni precum scorpionii (Apocalipsa 9, 3. 5). A doua fază își concentrează atenția asupra lăcustelor, asupra înfățișării lor, punându-i pe cei ce ascultă mesajul pe calea unei interpretări corecte, care va fi, în cele din urmă, aplicată istoriei umane ${ }^{28}$. Totuşi, autorul Apocalipsei corectează așteptările cititorilor lui, deoarece lăcustele despre care ne vorbește ,,au primit poruncă” fapt curios - să nu vatăme iarba pământului, și nicio verdeață, și niciun copac, ci numai oamenii (Apocalipsa 9, 4).

Invazia lăcustelor reprezintă o imagine simbolică și în paginile Vechiului Testament ${ }^{29}$. Intrarea lor în scenă nu e aşa cum ne imaginăm noi astăzi: un fel de țopăit jovial, ici-colo, pe câmp, a unor insecte nevinovate. Dimpotrivă, textul nostru descrie în o adevărată „,invazie”: nori deși de lăcuste care rad totul în calea lor, recoltele oamenilor fiind compromise iremediabil! Apariția lor reprezintă un flagel înspăimântător ${ }^{30}$.

${ }^{28}$ Ugo Vanni, Apocalisse di Giovanni, Secondo volume, A cura di Luca Pedroli, Assisi, Cittadella Editrice, 2018, p. 353.

${ }^{29}$ Imaginea aceasta apare pentru prima dată în Cartea Ieșirea 10, 12-15. E vorba de una dintre cele zece plăgi care s-au abătut asupra Egiptului, dar ea apare și la Profetul Ioil. Întreaga sa carte se naște dintr-o experiență sau dintr-un fapt obişnuit: o invazie cvadruplă de prădători care au compromis iremediabil întreaga recoltă: omizile, lăcustele, gândacii și tăciunele. Profetul Ioil a văzut în acest eveniment semnul pedepsei Domnului și al apropierii „Zilei Domnului”, ca zi de judecată asupra istoriei lui Israel (dar și asupra istoriei umane), moment descris cu accente eshatologice alcătuite din hiperbole și din metafore asociate temei cataclismelor naturale (amplificate de cataclisme cosmice), elemente specifice genului apocaliptic. Cf. Alexandru Moldovan, Profeții biblici, Alba Iulia, Edit. Reîntregirea, 2018, p. 620.

${ }^{30}$ Ugo VAnNi, Apocalisse, libro della Rivelazione, p. 105. 
„Trâmbița a cincea și primul «vai» (Apocalipsa 9, 1-11) o profeție care se implinește în zilele noastre?"

\section{Apocalipsa 9, 1-11 - scurtă interpretare}

Recurcând la imaginea invaziei de lăcuste, autorul Apocalipsei nu se mulțumește să ne-o prezinte pur și simplu: el o interpretează, o modifică și o adaptează, îmbogățind detaliile cu ,personaje” inedite: scorpioni, cai și căruțe pregătite de război, împăratul acestor forțe este ,îngerul adâncului”, al cărui nume, în evreiește, este „Abaddon”, iar în grecește „Apollion” (Apocalipsa 9, 11).

Cum și de undeapareacest nor dens de lăcuste? Scenariul este descris în Apocalipsa 9, 1-3. Totul pleacă de la o stea căzută din cer în momentul când s-a auzit sunetul celei de-a cincea trâmbițe. Această „stea” este mutată din locul ei firesc, de pe bolta cerească (cerul indică sălașul divinității; spațiul sacru prin excelență) în zona sau în spațiul profan (pământul). Această stea este ,personificată” și acționează pe pământ, având o misterioasă, dar reală, vitalitate. Ca și cum ar fi o ființă sau o persoană, acestei stele i-a fost dată „,cheia fântânii adâncului (abisului)" și 1-a deschis. Dacă e vorba de o „stea”, atunci vorbim despre un corp ceresc al cărui loc natrual și firesc este transcendentul. Totuşi, nu ne-am putea gândi la faptul că demonul sau slujitorii lui şi-ar putea găsi loc în cer (locul transcendenței divine), așa cum pare să ne spună pericopa din Apocalipsa 12, 7-12, deoarece în viziunea autorului Apocalipsei locul demonului este în abis. Textul nostru vorbește despre o prezență activă - și, într-un anume fel, de origine transcendentă, pentru că e ,o stea căzută din cer" - care nu poate fi înțeleasă sau evaluată numai la nivel omenesc ${ }^{31}$.

Puterea demonică activă pe pământ este „o stea” căzută din cer sau- de ce nu? - ,un înger căzut”. Această putere are capacitatea de a-și organiza intervenția în istorie și de a-și folosi din plin forțele de care dispune. În acest mod cred că trebuie înțeles simbolismul antropologic al „cheii”, simbolism care indică

${ }^{31}$ Gregory K. BEALE, The Book of Revelation. A Commentary on the Greek Text, New International Greek Testament Commentary, Michigan, Grand Rapids, Eerdmans Publishing, 1999, p. 699. 
capacitatea de a dispune (de a decide sau de a porunci) și, implicit, o autoritate, căci numai aceasta poate emite legi sau porunci. Subiectul activ în acest text este Dumnezeu Însuși: „,stelei căzute din cer i s-a dat cheia fântânii adâncului" (Apocalipsa 9, 1). Pasivul teologic subliniază, în acest text, ca și în alte locuri, concretețea istorică a situației în care se poate vedea o intervenție a lui Dumnezeu ${ }^{32}$.

Simbolismul antropologic al cheii este unit cu cel cosmic „al fântânii adâncului”, văzută de autorul cărții ca sălaș sau ca locuință a demonului. Termenul ,abis” (gr. $\dot{\alpha} \beta v ́ \sigma \sigma o v)$ se traduce ad-litteram cu „fântâna fără fund", expresie care în limba ebraică indică adâncul mării ${ }^{33}$, apele subterane ${ }^{34}$ și adâncurile pământului ${ }^{35}$. În

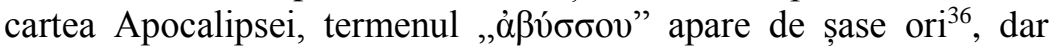
autorul ei e mult mai sobru și mai concis față de autorii altor scrieri apocaliptice, pentru care „fântâna adâncului” reprezintă haosul, identificat, la rândul său, cu sălașul demonului. Ideea adâncimii sau a prăpastiei fără fund, evocată în expresia „fântâna adâncului”, indică maximul răutății (ca și în cazul cifrei „,666” din Apocalipsa 13, 18, sau ca în expresia ,porțile iadului”, din Matei 16, 18).

Abisul sau adâncul reprezintă zona cea mai adâncă a mării sau a oceanului. În viziunea biblică, adâncul sau abisul reprezintă sau indică sălașul demonului (Șeolul, adică locul subpământean asemănător Infernului, care, la asiro-babiloneni și la evrei, reprezintă locuința sufletelor după moarte până la judecata de apoi. Este închipuit ca un ținut al întunericului și al umbrelor morților, unde lumina este totuna cu întunericul). Autorul Apocalipsei preia această imagine din cultura timpului său și se foloseşte de ea pentru a indica momentul în care această stea, căzută din cer pe pământ, deschide această fântână a adâncului ${ }^{37}$.

${ }^{32}$ Ugo VAnNi, Apocalisse di Giovanni, p. 355.

${ }^{33}$ A se vedea următoarele texte: Facerea 1, 2; Iov 38, 16; Isaia 51, 10; Iezechiel 26, 19; Iona 2, 6.

${ }^{34}$ Deuteronomul 8, 7 .

35 Psalmi 70, 23.

${ }^{36}$ A se vedea: Apocalipsa 9, 1-2. 11; 11, 7; 17, 8 și 20, 1. 3.

${ }^{37}$ Gregory K. BEALE, The Book of Revelation, p. 713. 
„Trâmbița a cincea și primul «vai» (Apocalipsa 9, 1-11) o profeție care se implinește în zilele noastre?"

Autorul trece de la o afirmație generală despre posibilitatea ca puterile demonice să acționeze pe pământ, la acțiunea concretă. Folosind ,cheia” care i-a fost dată, steaua căzută din cer eliberează puterile sale pe pământ. Această ,invazie” este prezentată cu ajutorul unei serii de simboluri, care pretind o atentă ,decodificare”.

Fântâna sau puțul adâncului este, la început, închis, iar conținutul său nu se poate revărsa sau nu poate ieși la suprafață decât numai atunci când este deschis. Deschiderea fântânii adâncului depinde de „cheia” care-i este dată unei stele căzute din cer, așa cum am văzut, de Dumnezeu (indicat indirect printr-un pasiv teologic). Asta înseamnă că toată activitatea sau acțiunea demonică pe pământ, oricum sau în orice fel s-ar configura sau s-ar manifesta, aceasta rămâne mereu sub controlul lui Dumnezeu ${ }^{38}$.

Se deschide această fântână și din ea se ridică un fum dens sufocant ${ }^{39}$. Puterea acestui fum de a polua pământul este subliniată de densitatea lui, întrucât e asemănat cu ,fumul unui cuptor mare" (Apocalipsa 9, 2). Fumul întunecă fața pământului, ascunzând lumina soarelui și poluează aerul. Imaginea fumului dens care ascunde lumina soarelui reprezintă un mesaj precis și clar adresat responsabilității umane; un mesaj pe care ni-l transmite răul însuși. Principiul pe care s-a construit sistemul terestru este profitul sau câștigul cu orice preț, câștigul în folosul propriu, egoist și orb, un principiu care se va dovedi, până la urmă, falimentar.

Puterea demonică prezentă pe pământ și simbolizată prin acel fum dens, este prezentată mai departe: din acest fum dens iese norul de lăcuste ${ }^{40}$, care tulbură întregul pământ. $\mathrm{Cu}$ deschiderea ,fântânii adâncului" începe atacul lăcustelor, care se concentrează, nu cum ar fi fost firesc, asupra ierbii, asupra verdețurilor sau asupra copacilor,

${ }^{38}$ Ugo VAnNi, Apocalisse di Giovanni, p. 355.

${ }^{39}$ Fumul gros care se ridică din fântâna adâncului are şi el o semnificație precisă: el modifică și strică ambientul pe care-1 invadează, ascunde lumina soarelui, poluează aerul necesar respirației și tulbură echilibrul vital. În spaţiul locuit de oameni - pe care-1 numim „lume” - există o presiune negativă care-i alterează fizionomia. Așa își face apariția un ambient artificial, plin până la saturație de rău sau de răutate.

${ }^{40}$ Aluziile la episoade din Vechiul Testament sunt evidente și ne sugerează deja o linie de interpretare: e vorba de un flagel îngăduit de Dumnezeu pentru a-i îndrepta pe oameni spre pocăință sau pentru a-i îndemna spre săvârşirea binelui. 
ci asupra oamenilor - şi aici e strecurat un detaliu important - nu asupra tuturor oamenilor, ci doar asupra celor „,care nu au pecetea lui Dumnezeu (litera grecească «tau») - t sau T, pe frunțile lor" (Apocalipsa 9, 4).

Porunca dată norului de lăcuste reprezintă un „stop” al elementului simbolic ${ }^{41}$, căci, așa cum am văzut, lăcustele nu trebuie să distrugă ceea ce distrug ele de obicei: recoltele, iarba câmpului sau frunzele copacilor, ci îi atacă pe oameni, dar fără să-i ucidă, ci doar lovindu-i și tulburându-i peste măsură, pentru o perioadă de timp limitată (textul biblic vorbește de „cinci luni”). Atacul lăcustelor seamănă cu înțepătura veninoasă a scorpionului care provoacă multă durere la oameni, iar în unele cazuri, dacă nu se intervine pentru îngrijirea lor, chiar moartea.

Lăcustelor „le este dată" 42 o putere cu totul inedită și străină de natura lor: puterea scorpionilor, a căror înțepătură este cunoscută de experiența oamenilor. Scorpionii înțeapă și introduc în corpul oamenilor, prin înțepătură, veninul care le produce multă durere, însă acesta este doar în foarte puține cazuri mortal. Puterea dată lăcustelor în acest text seamănă cu acest gen de înțepătură și de durere. Nu este precizată supărarea sau necazul pe care înțepătura lăcustelor o va provoca oamenilor, dar textul indică foarte clar ,o limită" importantă impusă de Cel care le-a dat putere să acționeze pe pământ: vor fi scoși din raza lor de acţiune oamenii care au pe frunțile lor ,,pecetea lui Dumnezeu”, sau cei 144 de mii despre care autorul cărţii a vorbit mai devreme, în capitolul 7.

Autorul insistă pe faptul că puterea lăcustelor are o limită impusă de Dumnezeu (este folosit din nou pasivul teologic) și ne indică precisa cea stă limită: lăcustele nu le vor aduce oamenilor moarte, ci doar suferinţă sau chin ${ }^{43}$. Chiar și perioada de chin este

${ }^{41}$ Ugo VAnNi, Apocalisse, libro della Rivelazione, p. 106.

42 Şi de data aceasta avem un pasiv teologic, aşa cum am avut în Apocalipsa 9, 1; subiectul subînțeles e Dumnezeu Care, acționând ca Stăpân absolut al naturii, transformă elementele acesteia și le recreează după bunul plac.

43 Termenul grecesc „, $\beta \alpha \sigma \alpha v \imath \sigma \theta \eta ́ \sigma o v \tau \alpha \imath ”$ este generic şi, prin acest fapt, autorul pune presiune asupraascultătorilor și asupra cititorilor săi, care se vor întreba despre ce fel de necaz sau de suferință este vorba? 
„Trâmbița a cincea și primul «vai» (Apocalipsa 9, 1-11) o profeție care se implinește in zilele noastre?"

limitată la „cinci luni”. Avem aici un simbolism numeric greu de interpretat, deoarece numărul cinci nu este unul specific Apocalipsei. Oricum, chinul sau suferința oamenilor va fi limitată la o perioadă sau la un interval de timp precis. Faptul acesta sporește tensiunea interpretării: în ce anume ar putea consta acest necaz sau această suferință limitată, care nu duce la moarte? Autorul cărții ne oferă un răspuns la această întrebare, dar o face în termeni simbolici: suferința produsă de înțepătura lăcustelor este comparată cu suferința cauzată de înțepătura scorpionului: „li s-a dat lor putere precum (gr. $\dot{\varsigma})$ au putere scorpiile pământului" (Apocalipsa 9, 3. 5).

Textul biblic continuă spunând că ,,în zilele acelea oamenii vor căuta (vor dori) moartea și nu o vor afla, căci moartea însăși va fugi de ei" (Apocalipsa 9, 6). Textul sugerează o antiteză între suferința provocată oamenilor de lăcuste și moarte. Dintre cele două, oamenii o vor prefera pe cea de-a doua! Ce suferință ar putea fi mai rea decât moartea? Exprimarea autorului intensifică în cititorul cărții dorința de a ști ce fel de suferință ar putea fi aceasta. $\mathrm{Cu}$ această hiperbolă aghiograful atinge culmea tensiunii literare şi încheie prima parte a prezentării sale ${ }^{44}$.

Ceea ce urmează pare să ne ofere fizionomia concretă a lăcustelor, determinată istoric, dar și un răspuns la întrebarea formulată mai devreme și la care cititorul cărții așteaptă un răspuns de la autorul ei: „Ce suferință ar putea fi mai rea decât moartea?”.

Autorul îi oferă cititorului indicii concrete legate de înfățișarea lăcustelor, înfățișare pe care el va trebui s-o recunoască în timpul istoric pe care-l trăiește. Construcția frazei cu ajutorul

${ }^{44}$ Imaginea unei suferințe mai rele decât moartea apare și în literatura popoarelor care-1 înconjurau pe Israel. În Vechiul Testament o regăsim în Cartea Profetului Ieremia: „Și toți ceilalți care vor rămâne din acest neam rău vor dori moartea în locul vieții, în toate locurile pe unde îi voi izgoni, zice Domnul” (Ieremia 8, 3). Moartea este preferată în locul unei vieți trăite sub semnul pedepsei lui Dumnezeu! Imaginea aceasta apare și în Cartea Iov: „Pentru ce dă Domnul lumina vieții celui nenorocit și zile celor cu sufletul amărât; Celor ce așteaptă moartea, şi ea nu vine, și care scormonesc după ea mai mult ca după o comoară; Celor ce se bucură cu bucurie mare şi sunt plini de fericire fiindcă au găsit un mormânt" (Iov 3, 20-22). Omul care așteaptă moartea și aceasta nu vine e un nefericit care se chinuie încercând, în zadar, să afle taina sau misterul suferinței. 
structurii septenare este cât se poate de îngrijită și de rafinată; seria de şapte - atât de îndrăgită de autorul cărții ${ }^{45}$ - indică totalitatea sau plenitudinea, iar asta înseamnă că tabloul sau imaginea lăcustelor care însoțește sunetul celei de a cincea trâmbițe este complet ${ }^{46}$.

Care este semnificaţia acestei descrieri simbolice? Autorul însuși ne oferă o cheie de interpretare neobișnuită în versetele 7-12.

Scenariul este foarte dens, însă imaginea care predomină este cea a războiului violent, voit și orchestrat de oamenii puternici, de conducători sau de oameni de stat. Lăcustele sunt oamenii care activează violența și războiul ${ }^{47}$. Lăcustele ,,sunt asemenea unor cai pregătiți de război”, fapt care sugerează ideea unui conflict orchestrat și bine organizat; celelalte indicii se referă la fizionomia lor: ,pe cap aveau cununi ca de aur, fețele lor erau asemenea fețelor oamenilor, părul lor ca părul de femei, și dinții lor ca dinții leilor, și platoșele lor ca platoșele de fier, iar vuietul aripilor lor era la fel cu vuietul unei mulțimi de care şi de cai care aleargă la luptă" (Apocalipsa 9, 7-9).

Termenul grecesc „ő $\mu$ ol $\alpha$ ” indică o corespondență de identitate între lăcuste și caii pregătiți de război, imagine care susține metafora belică, confirmată, puțin mai încolo, de aluzia la platoșe (gr. $\theta \omega ́ \rho \alpha \kappa \alpha \varsigma)$ și la vuietul cailor și al carelor care se lansează în luptă. Caracterul hibrid al fizionomiei lăcustelor care e în răspăr cu natura lor este un motiv de uimire și de teamă ${ }^{48}$.

Cununile de aur așezate pe capul cuiva reprezintă, în viziunea Apocalipsei, condiția transcendentă, care-1 pune pe cel ce poartă cununa în contact direct cu Dumnezeu (indicat prin imaginea aurului $^{49}$. În cazul lăcustelor, aghiograful folosește expresia „ca

45 „Șapte stele” $(1,16)$, „șapte sfeșnice de aur” $(1,20)$, „șapte epistole”/,șapte Biserici” (cap. 2 și 3), „cartea cu șapte peceți” (cap. 5), ,șapte îngeri” (cap. 8), "șapte trâmbițe" (cap. 8, 9, 10, 11), ,șapte cupe ale mâniei” (cap. 15, 16, 17), Mielul cel înjunghiat din cap. 5 are „şapte coarne și șapte ochi”.

${ }^{46}$ Ugo Vanni, Apocalisse di Giovanni, p. 359.

${ }^{47}$ IDEM, Apocalisse, libro della Rivelazione, p. 106.

${ }^{48}$ Giancarlo BiguZZI, Apocalisse, p. 206.

49 Fiul Omului poartă cunună și cingătoare de aur (Apocalipsa 1, 13), iar cei douăzeci și patru de bătrâni poartă cununi de aur pe care le aruncă (în semn de cinstire) înaintea tronului lui Dumnezeu (Apocalipsa 4, 10). 
„Trâmbița a cincea și primul «vai» (Apocalipsa 9, 1-11) o profeție care se implinește în zilele noastre?'

(gr. öHotoı) de aur", indicând prin ea o transcendență falsă, arogantă și uzurpată. Puterea demonică se prezintă înaintea oamenilor cu această pretenție și tinde să pătrundă în istoria lor, însușindu-și locul care I Se cuvine numai lui Hristos. De fapt, diavolul a avut curajul și îndrăzneala de a-I cere lui Hristos Însuși adorare și cinstire (Matei 4, 9; Luca 4, 5-6).

Textul spune că lăcustele aveau fețe „,ca niște fețe de oameni", detaliu care indică faptul că puterea demonică nu acționează singură, ci o face prin oameni (persoane singure sau structuri corupte) $)^{50}$.

Există în textul nostru și o referire discretă la ,părul femeilor". Pentru a interpreta expresiile obscure ale textului, e necesar să facem o trimitere scurtă la o altă operă (la o scriere apocrifă, de data aceasta), e vorba de „Apocalipsa lui Petru”, o operă posterioară Apocalipsei lui Ioan, în care se vorbește despre „părul femeii” ca element de seducție ${ }^{51}$.

Descrierea simbolicăa lăcustelor nu se oprește aici;dinții acestora sunt „ca dinții leilor”, indiciu care face trimitere la ferocitatea fiarelor. Puterea demonică este prezentă și se manifestă între oameni printr-o violenţă brută și feroce. Platoșele lor erau „,ca platoșele de fier", o nouă aluzie la o armată bine dotată și bine pregătită ${ }^{52}$. Zgomotul aripilor lor reprezintă ultimul indiciu care reia ideea inițială exprimată în versetul 3: „din fumul gros au ieșit lăcuste", care au produs un zgomot asemănător vuietului unei mulțimi de care de război trase de cai care aleargă la luptă.

Întregul context este dominat de imaginea unui război crud și total, iniţiat de oameni și localizat pe întregul pământ. Acum, nu toate războaiele sunt îndreptate împotriva lui Hristos și a Bisericii

${ }^{50}$ Ugo VAnNi, Apocalisse di Giovanni, p. 360.

51 „Și din nou, iată, alte femei: erau legate de gât și de păr și aruncate în groapă. Sunt cele care își împletesc părul, dar nu pentru bine, ci pentru a se deda desfrâului; astfel putând să amăgească și să atragă sufletele bărbaților spre pierzanie". (Apocalipsa lui Petru, 7). Avem în acest text o paralelă cu textul canonic din 1 Petru 3, 3 ,Podoaba voastră să nu fie cea din afară: împletirea părului, podoabele de aur și îmbrăcarea hainelor scumpe". Ugo VANNI, Apocalisse, libro della Rivelazione, p. 106.

${ }^{52}$ IDEM, Apocalisse di Giovanni, p. 360. 
Sale, dar orice război este devastator și crud, un lucru nedorit, atât pentru cei care-l pornesc, dar mai ales pentru cei care sunt constrânși să-1 suporte ${ }^{53}$.

Putem afirma că puterea demonică și prezența ei pe pământ, în toate formele și variantele ei de manifestare, îi lovește și îi rănește pe oameni din interior, așa cum face veninul inoculat în trupul lor de înțepătura scorpionului sau de mușcătura şarpelui ${ }^{54}$.

Asistând la acest scenariu, cititorul Apocalipsei poate simţi în ființa sa profundă o durere, ca o ,înțepătură” de scorpion, care-1 determină să afirme că sistemul actual al lumii și al oamenilor nu mai funcționează sau că acesta nu mai poate continua așa. E aceeași durere sau neplăcere sufletească (interioară) a celui care a observat și a constatat - în seria trâmbițelor precedente - ,violența" oamenilor asupra naturii și asupra lumii înconjurătoare ${ }^{55}$.

Conștientizarea răului și a lucrării lui în lume și între oameni produce în noi o tulburare aproape insuportabilă, dacă I-am rămas fideli lui Dumnezeu și Legământului pe care El 1-a încheiat cu noi în Iisus Hristos. Textul nu vorbește doar de surpriza dureroasă și neplăcută pe care omul o simte înaintea formelor de manifestare ale răului, ci de o neliniște apăsătoare de care el ar vrea să scape. Omul care a ales ura și violența, în formele ei cele mai frapante, precum războiul, aservirea și subjugarea altora și falsa transcendență, va ezita, va opune rezistență și va lupta împotriva unei schimbări interioare (a unei convertiri) radicale ${ }^{56}$.

Înțelegem acum că întregul scenariu descris în această pericopă, oricare ar fi semnificația lui, îl invită pe cititorul ei la pocăință. Dar e posibil ca îndemnul pe care omul îl primește de a-şi schimba viața să nu fie înțeles, sau să nu fie acceptat, pentru că oamenii sunt ,tari în cerbice și netăiaţi împrejur la inimă și la urechi” (Fapte 7, 51). E posibil... E posibil să-ți vină gândul sau imboldul de a-ți schimba viața, dar firile ezitante se pot bloca, sau pot prefera moartea în locul schimbării și al pocăinței.

\footnotetext{
${ }^{53}$ IDEM, Apocalisse, libro della Rivelazione, p. 107.

${ }^{54}$ IDEM, Apocalisse di Giovanni, p. 361.

${ }^{55}$ Ugo VAnNi, Apocalisse, libro della Rivelazione, p. 107.

${ }^{56}$ IDEM, Apocalisse di Giovanni, p. 361.
} 
„Trâmbița a cincea și primul «vai» (Apocalipsa 9, 1-11) o profeție care se implinește în zilele noastre?"

Scopul acestor flageluri, calamități, dezastre, boli, epidemii și molime, permise sau îngăduite de Dumnezeu, este pocăința sau întoarcerea la El prin pocăință, așa cum rezultă din textul din Apocalipsa 9, 20-21. Cu alte cuvinte, există un timp al pocăinței, un timp al întoarcerii, pentru că Dumnezeul nostru este „Dumnezeul celor ce se întorc şi se pocăiesc", un timp indicat în textul nostru prin sintagma „,cinci luni” (Apocalipsa 9, 10). Dumnezeu îi dă omului timp să se pocăiască, timp în care omul simte tulburarea (înțepătura) crizei în care se află atunci când dorește să-și schimbe viața $^{57}$.

Momentul convertirii poate fi resimţit într-o formă atât de dramatică şi acută, încât poate face credibilă și plauzibilă exprimarea autorului Apocalipsei din versetul 6: „Și în zilele acelea oamenii vor căuta moartea și nu o vor afla și vor dori să moară; moartea însă va fugi de la ei”. Autorul cărții își descoperă genialitatea interpretativă, făcându-ne să înţelegem, printr-o exprimare foarte inspirată, că oamenii, decât să-și schimbe radical viața, ar prefera s-o piardă! ${ }^{58}$

Atunci când omul se decide să-și schimbe viața, începe în sufletul său o luptă. De cele mai multe ori, dacă nu în toate cazurile, „omul cel vechi” opune rezistență, iar pe Dumnezeu îl vede ca pe un vrăjmaș, pentru că nu e deloc ușor să ne debarasăm de patimi, nu e deloc uşor să o rupem cu păcatul și cu obiceiurile păcătoase, nu e ușor să renunțăm la o viață comodă și liniștită, nu e ușor să renunțăm la mediocritate și la superficialitate în ceea ce privește viața noastră spirituală. Însă, Dumnezeu nu-i dă omului pace și liniște și nu-i îngăduie odihnă. Chiar dacă-i respectă omului

${ }^{57}$ Un asemenea moment este descris şi de Fericitul Augustin, în Confesiunile sale: „În sfârșit, în învălmășeala tuturor şovăielilor mele, făceam tot felul de mișcări, aşa cum se întâmplă adesea ca oamenii să dorească să facă ceva și să nu fie în stare, fie pentru că nu au brațe, fie pentru că acestea le sunt încătușate în lanțuri, moleșite de oboseală sau împiedicate în orice fel. Îmi smulgeam părul din cap, îmi izbeam fruntea cu pumnii, îmi îmbrățișam genunchii cu degetele încleștate”. Sfântul Augustin, Confesiuni, Cartea a VIII-a, 8, 20, trad. Eugen Munteanu, București, Edit. Humanitas, 2018, p. 369.

${ }^{58}$ Ugo VANNI, Apocalisse, libro della Rivelazione, p. 107. 
libertatea, Dumnezeu îl solicită în fiecare zi, în fiecare ceas, îl „chinuie” în fiecare clipă, așteptând întoarcerea lui ${ }^{59}$.

După ce ne-a prezentat fizionomia lăcustelor și răul sau chinul pe care acestea îl produc oamenilor, autorul ne spune că această armată teribilă care acționează pe pământ are un conducător, are ca lider pe ,îngerul abisului sau al genunii" sau pe ,îngerul adâncului” (Apocalipsa 9, 11). Acest înger al adâncului are un nume precis: „Abaddon”/,Apollion”, care le conduce și le organizează. Numele acestui înger face trimitere la locul însuși în care-și are sălașul puterea demonică: abisul sau genunea.

E un nume propriu (gr. ơvo $\mu \alpha \alpha$ v่ $\tilde{\omega}$ ) redat atât în limba ebraică, cât și în limba greacă, fapt care implică o personalizare, cel puțin de ordin literar, dacă nu și teologic, o fizionomie precisă și o referire la texte vechi testamentare ${ }^{60}$.

Aceste texte ne oferă un indiciu precis: cuvântul „Abaddon” face trimitere la ideea distrugerii, în timp ce acelaşi cuvânt în limba greacă „Apollion"61 înseamnă distrugător sau devastator în sens activ. Autorul trece de la un substantiv (Abaddon) la participiul unui verb (Apollion), care exprimă în termeni activi sensul abstract

59 Alexandru Moldovan, Propedeutică biblică. De la Primordiu la Răscoala Macabeilor. Cărțile cu caracter istoric, Alba Iulia - Stockholm, Edit. Reîntregirea - Edit. Felicitas, 2019, p. 248.

60 În Cartea Iov, în capitolul 28, autorul vorbește despre izvorul înțelepciunii, iar în versetul 22 spune: „Adâncul (Abisul) - în Textul Masoretic, Abbadon, iar în Septuaginta, $\hat{\alpha} \pi \omega \dot{\lambda} \varepsilon 1 \alpha$ - și moartea au zis: Noi am auzit vorbindu-se de ea”. În aceeași carte, în capitolul 31, autorul vorbește despre ,un foc care mistuie până la iad (până la distrugere) - în Textul Masoretic, Abbadon, iar în Septuaginta, $\dot{\alpha} \pi \omega \dot{\lambda} \varepsilon \sigma \varepsilon v$ - și care nimicește toată agoniseala mea" (v. 12). În Cartea Pildelor lui Solomon, în capitolul 15, se spune că „Iadul şi adâncul (Abisul) - în Textul Masoretic, Abbadon, iar în Septuaginta, $\alpha \dot{\alpha} \omega \dot{\lambda} \varepsilon 1 \alpha$ - sunt cunoscute Domnului, cu atât mai vârtos inimile oamenilor” (v. 11), iar în Psalmul 87, 12 avem următoarea exprimare: „Oare va spune cineva în mormânt mila Ta și adevărul Tău în locul pierzării (sau în împărăția morții) - în Textul Masoretic, Abbadon, iar în Septuaginta, $\alpha \dot{\pi} \omega \dot{\lambda} \varepsilon 1 \alpha$ - ? Ugo VANNI, Apocalisse di Giovanni, p. 362.

61 Exista în vechime o afinitate etimologică între numele ,'A $\mathrm{Ao} \lambda \lambda \hat{v} \omega v$ " și ,'A $\pi$ ó $\lambda \lambda \omega v "$, dar e destul de greu săcredem că autorul Apocalipsei a vrut să ni-l prezinte pe zeul Apollo din panteonul păgân (zeul tinereții și al muzicii) ca pe un ,distrugător”. 
„Trâmbița a cincea și primul «vai» (Apocalipsa 9, 1-11) o profeție care se implinește în zilele noastre?"

al substantivului. În acest fel, se întâmplă o transformare interesantă: realitatea abisală (Abaddon) devine - prin noul nume în grecește (Apollion) - o forță concretă și tulburătoare, care acționează printre oamenii de pe pământ. Astfel ,îngerul adâncului” reprezintă distrugerea de natură abisală personificată și total distructivă care se extinde în istoria umană.

Aceasta pare să fie perspectiva în care se mișcă autorul Apocalipsei, care presupune că auditoriului său îi este familiară istoria Vechiului Testament şi limba ebraică. Folosind ambele nume, atât numele în limba ebraică (Abaddon), cât și cel în limba greacă (Apollion), el sugerează ideea că răul care acționează pe pământ - lucrare sau acțiune indicată prin imaginea lăcustelor - are o rădăcină abisală. În acest fel, forța răului estebine determinantă și dobândește o fizionomie precisă: abisul sau genunea din tradiția iudaică, citit în termenii concreți ai mediului grecesc (al destinatarilor cărții) devine „distrugătorul” sau „devastatorul”.

„Primul «vai» a trecut; iată vine încă un «vai» și încă unul după acestea” (Apocalipsa 9, 12). Repetarea interjecției „vai” de trei ori subliniază gravitatea sau seriozitatea situației. O serie sau o avalanșă de necazuri se va abate asupra pământului și asupra oamenilor care locuiesc pe el. Cele trei „vai”-uri reprezintă strigătul de durere al Cerului și anunță pedepse diferite. Omul nu trebuie săși facă iluzii, pentru că nu va scăpa de mânia lui Dumnezeu, dacă faptele lui sunt rele şi dacă nu se va întoarce prin pocăință. Flagelurile provocate de cele trei ,vai”-uri vor fi inexorabile.

\section{Privire teologică de ansamblu}

După ce ne-a prezentat, în mod repetat, în primele patru trâmbițe ideea prezenței active a lui Dumnezeu în istorie, ca forță propulsoare spre o lume nouă (sau înnoită), cu cea de a cincea trâmbiță - Apocalipsa 9, 1-11 - autorul schițează o primă descriere sau un prim tablou al unui nou protagonist (antitetic de această dată) al istoriei care se opune în mod voalat sau chiar fățis împotriva planului de mântuire al lui Dumnezeu: demonul se insinuează și se infiltrează în structurile umane și în viețile oamenilor, dar și în 
evenimentele care se succed pe scena istoriei lor: conflicte, războaie, violență, ură, crimă, ferocitate și false valori divinizate ${ }^{62}$.

Grupului eclezial - unul dintre personajele active ale cărții Apocalipsei - care cunoaște bine aceste fapte, îi este sugerată lectura sapiențială - ,în Duhul" - a evenimentelor. Chiar dacă toate stau „sub ochii Domnului” și sub purtarea Lui de grijă, toate evenimentele istoriei cuprind în ele o greutate sau o povară, un aspect negativ care derivă din lucrarea Răului. Astfel că, de multe ori, evenimentele istoriei umane ne descumpănesc, ne contrariază și ne tulbură, sunt fără sens sau absurde din punct de vedere omenesc, tocmai pentru că absurdul este un ingredient al Răului ${ }^{63}$.

Aceste lucruri negative, privite sau înțelese în mod corect (în sens duhovnicesc), înțeapă, rănesc și provoacă durere „din interior”, la fel cum se întâmplă cu înțepătura scorpionului. Însă, dacă privești lucrurile duhovnicește, aceleași lucruri negative ar putea deveni un imbold spre o schimbare radicală (spre pocăinţă) pentru cei care sau lăsat seduși sau amăgiți de lucrarea Răului.

$\mathrm{Nu}$ greșim dacă vedem în acest lucru o pedagogie divină, o încercare a Creatorului de a-Și corecta sau de a-Și îndrepta creatura, câtă vreme Dumnezeu îngăduie încă lucrarea Celui Rău în istoria noastră urmărind, prin aceasta, o finalitate pozitivă, chiar dacă această stranie pedagogie îi provoacă omului neînțelegere și o profundă și o chinuitoare neliniște ${ }^{64}$.

Totuşi, tulburarea care derivă din aceste evenimente și fapte neînțelese nu-i va atinge pe cei care L-au primit pe Dumnezeu în viața lor, deoarece ,celor care L-au primit, care cred în numele Lui (Hristos), le-a dat putere ca să se facă fii ai lui Dumnezeu” (Ioan 1, 12). În aceștia nu mai decid carnea și sângele, care, oricum, ,nu pot să moștenească Împărăția lui Dumnezeu” (1 Corinteni 15, 50), nici pofta trupească și nici pofta bărbătească, pentru că ei ,sunt născuți din Dumnezeu". În plus, cei care L-au primit (pe Hristos) au fost

62 André Feulllet, L'Apocalypse, état de la question, Studia Neotestamentica, Subsidia 3, Paris, Desclée, 1963, p. 221.

${ }^{63}$ Giancarlo BiguzZi, L 'Apocalisse, p. 210.

${ }^{64}$ David E. Aune, Revelation 6-16 (Word Biblical Commentary 52B), Michigan, Grand Rapids, 1998, p. 531. 
„Trâmbița a cincea și primul «vai» (Apocalipsa 9, 1-11) o profeție care se implinește în zilele noastre?"

pecetluiți cu Duhul Sfânt (Efeseni 1, 13; 4, 30), „Care este arvuna moștenirii noastre, spre răscumpărarea celor dobândiți de El și spre lauda slavei Sale" (Efeseni 1, 14). Cu toate acestea, credincioșii nu sunt scutiți de efectele negative ale lucrării celui rău, dar ei pot lectura și pot interpreta în mod diferit sensul acesteia, din perspectiva credinței pe care o poartă în sufletele lor ${ }^{65}$.

Există presiuni multiple asupra oamenilor (cu precădere asupra oamenilor care trăiesc o viață cu Dumnezeu) și asupra lumii; lumea pe care o știm noi cunoaște din plin efectele căderii: bolile, distrugerea, conflictele armate, moartea sau, pur și simplu, falimentul organizării viețiipolitice și sociale. Ciudat este faptul că acest aspect negativ al vieții nu e suficient pentru a-l determina pe om spre pocăință ${ }^{66}$. La asta se ajunge numai atunci când apare cineva care, prin viața și exemplul lui, promovează viața în Hristos, sau viața așa cum ne-a indicat-o Hristos.

Profeții biblici aparțin modului de viață propus lumii de Mântuitorul Hristos. Vocea profeților (glasul Bisericii animată de Duhul Sfânt și a martorilor ei care I-au dat mărturie lui Hristos și Evangheliei Sale), lovesc în plin sistemul pământesc. Acesta poate reacționa - și a și făcut-o în decursul istoriei - în mod violent și refractar (începând cu primul martor sau mărturisitor creștin, care a fost Sfântul Arhidiacon Ștefan), însă această presiune, care e un efect al mărturiei corale a Bisericii Universale și al sacrificiului martorilor (martirilor) ei, poate avea ca efect minunat trecerea oamenilor de la sistemul pământesc la Împărăția lui Hristos ${ }^{67}$.

Se deschide, astfel, o perspectivă mai amplă și, în același timp, nouă: odată cu depăşirea, prin credință și mărturisire, a sistemului pământesc, își face loc o situație diferită, pozitivă și definitivă în același timp, cea pe care autorul Apocalipsei o va descrie amănunțit în secțiunea care urmează, a celor trei semne: „Femeia înveșmântată cu soarele” („marele semn”), semnul „Balaurului roșu” și semnul celor „Șapte îngeri care poartă în mâinile lor cele șapte cupe ale mâniei lui Dumnezeu"68.

${ }^{65}$ Ugo Vanni, Apocalisse, libro della Rivelazione, p. 107.

${ }^{66}$ David E. AunE, Revelation 6-16, p. 536.

${ }^{67}$ Pierre Prigent, L 'Apocalisse di S. Giovanni, p. 536.

${ }^{68}$ Ugo VAnNI, Apocalisse di Giovanni, p. 336. 
Apropierea lui Dumnezeu de lume și de faptele pe care le săvârșesc oamenii, apropiere anunțată și confirmată ,în crescendo" de sunetul celor șapte trâmbițe, se va exprima prin evenimente tulburătoare, evenimente care reprezintă falimentul istoric al unei concepții, al unei filozofii și a unui mod de viață închis față de transcendență și faţă de iubirea lui Dumnezeu. Evenimentele catastrofale care-i produc omului frică și angoasă nu depind de Dumnezeu și nu reprezintă consecința judecății Lui; atitudinea omului de a se închide înaintea transcendenței şi care poartă pecetea răului, edificând structuri violente și nedrepte, va fi cauza distrugerii lumii și a tot ceea ce a fost adus de Domnul la ființă sau la existențăa9 .

Egoismul absolutizat, specific sistemului pământesc de organizare a lumii, transformă pământul într-un pustiu potrivnic vieții și neproductiv. Judecata divină exprimată înaintea faptului că omul se degradează și se distruge singur, și împreună cu el întreaga creație, este cu totul negativă, dar autorul Apocalipsei nu vorbește despre o pedeapsă inexorabilă sau implacabilă, ci despre o evaluare justă a faptului că sistemul pământesc de organizare a lumii poartă în el germenii autodistrugerii.

Primul pas al apropierii lui Dumnezeu de oameni vrea să-i conștientizeze pe aceștia de voința Sa. În secțiunea sau în seria trâmbițelor - din care pericopa pe care am analizat-o face parte există o mișcare descendentă explicită a lui Dumnezeu, care se desfăşoară în mai multe etape, cu scopul precis de a-i ajuta pe oameni să citească și să îțeleagă ,semnele vremii" ${ }^{\prime \prime 0}$, pentru a-i ajuta să-şi dea seama de eroarea fatală pe care o fac, atunci când se decid să se închidă în orizontul lor restrâns. Recurgând la toate resursele, Dumnezeu îi arată omului, cu anticipație, consecințele inevitabile care decurg din atitudinea lui și eroarea unui sistem de viață care poartă în el germenii autodistrugerii. Îndepărtarea omului de Dumnezeu, de transcendență, duce, într-adevăr, la declinul imanenței. Dumnezeu încearcă prin toate mijloacele și în toate

${ }^{69}$ IDEM, Apocalisse e Antico Testamento. Una sinossi, Roma, Pontificio Istituto Biblico, 2000, p. 136.

70 În special două dintre aceste „semne” sunt evidente: ruptura legăturii omului cu natura (cu creația) și diminuarea comuniunii dintre oameni. 
„,Trâmbița a cincea și primul «vai» (Apocalipsa 9, 1-11) o profeție care se implinește în zilele noastre?'

felurile să-1 readucă pe om în legătură cu El, în comuniune cu El, pentru că El S-a întrupat ,,pentru ca lumea să aibă viață și s-o aibă din belșug" (Ioan 10, 10).

Încă de la începutul operei sale, Sfântul Ioan își numește scrierea „Descoperire”, „Apocalipsă”, „Revelație” sau „Profeție” (Apocalipsa 1, 1-3). Prin gura profeților biblici, Dumnezeu a grăit, de multe ori, lumii și oamenilor din ea, a grăit popoarelor, îndemnându-le la pocăință, îndemnându-le să intre în planul Său de mântuire a lumii. Cartea Apocalipsei reprezintă o interpretare grandioasă a acestui plan, potrivit căruia Dumnezeu conduce istoria umană, făcând apel la oameni și la comunitățile creștine.

Cuvântul profetic se adresează responsabilității pe care omul, ca ființă rațională, o are înaintea Creatorului său, înaintea lumii și înaintea semenului său. Cartea Apocalipsei îi invită pe oameni să se considere și să se vadă „părtași activi” ai planului lui Dumnezeu de mântuire a lumii pe care a adus-o din neființă la ființă sau la existență, ,parte combatantă" a confruntării dintre forțele binelui și forțele răului, și să creadă cu tărie în Cel Care a biruit lumea (Ioan 16, 33).

$\cos 80$

\section{Bibliografie}

1. Sfântul Augustin, Confesiuni, Cartea a VIII-a, 8, 20, trad. Eugen Munteanu, București, Edit. Humanitas, 2018.

2. AunE, David E., Revelation 6-16 (Word Biblical Commentary 52B), Michigan, Grand Rapids, 1998.

3. BarZaghI, Anna, Apocalisse di Giovanni. Con commenti tratti dai Padri, Santi e Mistici della Chiesa, Bari, Edizioni Pugliesi, 2003.

4. BEALE, Gregory K., The Book of Revelation. A Commentary on the

Greek Text, New International Greek Testament. Commentary. Michigan - United Kingdom, Grand Rapis - Cambridge, 1999.

5. IDEM, The Book of Revelation. A Commentary on the Greek Text,

New International Greek Testament Commentary, Michigan, Grand Rapids, Eerdmans Publishing, 1999.

6. *** Biblia sau Sfânta Scriptură, București, Edit. Institutului Biblic și de Misiune Ortodoxă, 2018. 
7. BIGUZZI, Giancarlo, Apocalisse. Nuova versione, introduzione e commento (I Libri Biblici. Nuovo Testamento 20), Milano, Edizioni Paoline, 2011.

8. IDEM, L 'Apocalisse e $i$ suoi enigmi (Studi ed Esegesi Biblica 143), Brescia, Paideia Editrice, 2004.

9. CorsAnI, Bruno, L'Apocalisse e l'apocalittica del Nuovo Testamento, Bologna, 1997.

10. CORSINI, Eugenio, Apocalisse di Gesù Cristo secondo Giovanni, Torino, SEI, 2002.

11. Dianich, Severino, Sempre Apocalisse. Un testo biblico e le sue risonanze storiche, Casale Monferrato, Editrice Piemme, 1998.

12. Feuillet, André, L'Apocalypse, état de la question, Studia Neotestamentica, Subsidia 3, Paris, Desclée, 1963.

13. LANCELlOTTI, Angelo, Apocalisse. Nuovissima Versione della Bibbia 46, Roma, Edizioni Paoline, 1981.

14. LUPIERI, Edmondo, L'Apocalisse di Giovanni (Scrittori greci e latini), Milano, 1999.

15. Moldovan, Alexandru, Profeții biblici, Alba Iulia, Edit. Reîntregirea, 2018.

16. IDEM, Propedeutică biblică. De la Primordiu la Răscoala Macabeilor. Cărțile cu caracter istoric, Alba Iulia - Stockholm, Edit. Reîntregirea - Edit. Felicitas, 2019.

17. Prigent, Pierre, L 'Apocalisse di S. Giovanni (Commenti biblici), Roma, Edizioni Borla, 1985.

18. IDEM, L'Apocalisse di San Giovanni (Collana Commenti Biblici), Città di Castello, Edizioni Borla, 1985. Titlul original al operei: L'Apocalypse de Saint Jean (Commentaire du Nouveau Testament 14), Lausanne-Paris, Delachaux et Niestlé, 1981.

19. TAgliapetra, Andrea, Gioacchino da Fiore. Sull'Apocalisse, Milano, Editrice Feltrinelli, 1994.

20. VAnni, Ugo, Apocalisse di Giovanni, Primo volume, Assisi, Cittadella Editrice, 2018.

21. IDEM, Apocalisse di Giovanni, Secondo volume, A cura di Luca Pedroli, Assisi, Cittadella Editrice, 2018.

22. IDEM, Apocalisse e Antico Testamento. Una sinossi, Roma, Pontificio Istituto Biblico, 2000.

23. IDEM, Apocalisse, libro della Rivelazione. Esegesi biblico-teologica e implicazioni pastorali, Bologna, Edizioni Dehoniane, 2009.

24. ZEDDA, Silverio, „L'Escatologia dell'Apocalisse”, în L'escatologia biblica, Vol. 2, Brescia, 1974, p. 427-515. 